\title{
Forest Management and Adaptation Strategies in Response to Climate Change by the Taiwanese Public
}

\author{
Wan-Yu Liu ${ }^{1,2}$, Chien-Chen Wu ${ }^{1}$ (D) and Shih-Yu Simon Wang ${ }^{3,4, *(\mathbb{D})}$ \\ 1 Department of Forestry, National Chung Hsing University, Taichung City 40227, Taiwan; \\ wyliu@nchu.edu.tw (W.-Y.L.); gemini497586@gmail.com (C.-C.W.) \\ 2 Innovation and Development Center of Sustainable Agriculture, National Chung Hsing University, \\ Taichung City 40227, Taiwan \\ 3 Department of Plants, Soils and Climate, Utah State University, Logan, UT 84322, USA \\ 4 International Bachelor Program of Agribusiness, National Chung Hsing University, Taichung City 40227, Taiwan \\ * Correspondence: simon.wang@usu.edu; Tel.: +1-(435)-757-3121
}

Citation: Liu, W.-Y.; Wu, C.-C.;

Wang, S.-Y.S. Forest Management and Adaptation Strategies in Response to Climate Change by the Taiwanese Public. Atmosphere 2021, 12, 1056. https://doi.org/10.3390/atmos 12081056

Academic Editor: Riccardo Buccolieri

Received: 27 June 2021

Accepted: 12 August 2021

Published: 17 August 2021

Publisher's Note: MDPI stays neutral with regard to jurisdictional claims in published maps and institutional affiliations.

Copyright: () 2021 by the authors. Licensee MDPI, Basel, Switzerland. This article is an open access article distributed under the terms and conditions of the Creative Commons Attribution (CC BY) license (https:// creativecommons.org/licenses/by/ $4.0 /)$.

\begin{abstract}
Forests account for $60 \%$ of lands in Taiwan. Climate change impacts forests in many aspects and is increasingly likely to undermine the ability of forests to provide basic ecosystem services. To help reduce the impact of climate change on Taiwan's forests, people must be made aware of the relationship between climate change and forests. Based on questionnaires collected from 17 cities in Taiwan, this study applied spatial analysis to assess the respondents' understanding of climate change and adaptation strategies for forest management. A total of 650 questionnaires were distributed and 488 valid ones were collected. The results show that (1) Most respondents believe that climate change is true and more than half of the respondents have experienced extreme weather events, especially extreme rainfall; (2) Most respondents believe that climate change will affect Taiwan's forests with the majority recognizing the increasing impact of extreme events being the primary cause, followed by changes in the composition of tree species and the deterioration of forest adaptability due to climate change; (3) Most respondents expressed that forest management should be adjusted for climate change and called for measures being taken to establish mixed forests as well as monitoring forest damage; (4) In order to address the difficulties faced by forest owners on the impact of climate change, the majority of respondents felt that the government should raise forest owners' understanding on climate change and adaptation policies, while the subsidy incentives must also be adjusted. The results of this study show that the respondents do realize the importance of climate change and forest management so much so their awareness in this matter led to their support for forest adaptation measures and policies.
\end{abstract}

Keywords: climate change; awareness; adaptation; forest management; Venn diagram

\section{Introduction}

Worldwide, climate change has posed a significant threat to forests due to the increasing heat and aridity, shifting rainfall patterns and extreme weather events. Anthropogenic climate change impacts the growth and productivity of trees [1,2], tree health and composition of species $[3,4]$, and the extent to which trees are damaged by natural disturbances $[5,6]$. These impacts are harmful to the environmental, economic and societal values of all forests and could damage their noneconomic value, functions and services [7]. To mitigate climate change risks and reduce vulnerability of forests in the face of climate change, adequate adjustments to forest management policies are required [8]. Compared to agriculture, decision-making and planning in forest management are based on a much longer timeline, during which forests replenish and trees grow, mature and yield. Even after forests renew themselves, they must stand and face a potentially different climate and environment for decades if not centuries $[9,10]$. 
Most of Taiwan's forests are national forests and the management of which is considerably affected by public opinions and public awareness. Therefore, integration of forest adaptation policies requires the participation of the public. According to the Global Climate Risk Index published in 2018 by Germanwatch (in the 23rd Conferences of the Parties of the United Nations Framework Convention on Climate Change [11]), Taiwan ranks seventh among the regions with a high risk from climate change. The topography of Taiwan is towering and steep, with an uneven yet extreme rainfall pattern. Taiwan frequently undergoes direct impacts from tropical cyclones during summer and autumn and heavy monsoon rains that cause landslides and associated losses of forest. Episodic droughts also impacted the island. However, few studies have discussed the effects of climate change on Taiwan's forest management.

The forest coverage rate of Taiwan is $60.71 \%$, and Taiwanese forests are richly diverse in terms of forest physiognomy. Taiwan's forests are divided into four management zones: nature reserves areas, national protective areas, timber management areas and forest recreation areas. Since the nature reserves areas and national protective areas account for $79 \%$ of the entire forests, Taiwan's forest management policy is mainly for forest protection [12]. Given that the public's awareness of climate change matters in relevant policies on adapting to and reducing the impacts of climate change, this study applies descriptive statistics to analyze the public's understanding of climate change and forest management, as well as their views on the obstacles and potential solutions to the implementation of adaptation actions.

\section{Background}

The Intergovernmental Panel on Climate Change (IPCC) has directed a mitigation and adaptation strategy for solving the risk and impact of climate change [13]. Mitigation means implementing human interventions to mitigate the pressure of human activities on climate systems from the perspective of technology, economics and policies to reduce or impede global climate change. Adaptation refers to adapting according to actual or estimated climate change or influences on natural and human systems to reduce the impact of a specific risk or take advantage of beneficial opportunities. Adaptation can be divided into progressive and transitional adaptations [14]. Progressive adaptation is applying current knowledge and technology to respond to changing climate conditions, whereas transitional adaptation is expecting and reacting to multiple aspects with the aim of modifying a forest's adaptation ability or provoking a specific adaptation ability.

Since progressive adaptation may not be effective for species with long life expectancies, such as trees, Messier et al. [15] indicated that researchers must forecast changes in climate conditions instead of only observing them. In addition, transitional adaptation demands the participation of the entire forestry industry, from actual managers to decision-makers and forestry workers. Collaboration between managers and decisionmakers ensures that a forest fits the needs and preferences of the residents [16]. Advantages of such co-participation include a comprehensive foundation in policy support, enhanced information sharing and professional knowledge on adaptations in response to unique climate conditions [15,17].

Forest management and decision-making are based on the interactions of all participants and how they react to one another [18]. It is noteworthy that many of the various adaptation policies were applied to forest management before climate change became widely known, such as those proposed by Bolte et al. [19] and Kolström et al. [16]. For example, the back-to-nature measure focuses on provoking species mixing and an irregular age structure in an even-aged forest [20]. Even though the ecological perspective has confirmed that reintroducing a complex stand structure to forests is economical, most backto-nature measures are still production-oriented [21]. Another example is the systematic afforestation method. In contrast with the back-to-nature measures, which focus on a target structure or composition, systematic afforestation tends to follow and adjust intervention measures to adapt to natural reactions of each forest stand [18,21]. 
An increasing number of scholars have realized the viewpoints of forest owners on climate change and the importance of adaptation plans [22-26]. Joa and Schraml [27] indicated that the viewpoints on ecological value and forest adaption strategies are crucial for conservation on a landscape scale so that positive conservation perceptions can increase the chance of conservation implementation. Furthermore, effectiveness of forest governance depends on the public's support for forest management [28]. Public awareness also affects the acceptance of forest management strategies, which is important for the formulation and implementation of successful adaptation strategies, policies and actions [29-31]. Altinay [32] indicated that the public's awareness of climate change is closely correlated with their support of relevant policies for adapting and reducing the effects of climate change. In European countries, the public are commonly aware of climate change and concern about its impacts, and yet this awareness has not been translated into tangible adaptation actions due to the lack of knowledge and information [33]. These theories serve as the foundation for this study that focuses on Taiwan's forest management system.

Here, we apply the Kruskal-Wallis test and Spearman's correlation analysis to determine which perceptions are critical to influencing adaptation actions in the case of Taiwan. This study aims to (1) understand the public's awareness of climate change and forest adaptation strategies of Taiwan and (2) offer information for forestry-related authorities in Taiwan and enhance the information disseminated for understanding climate change and implementing relevant Adaptation policies.

\section{Materials and Methods}

The questionnaire includes four aspects: general understanding of climate change, experience of extreme weather events, ideas on potential impacts and implementation of adaptation actions. The questionnaire was based on the literature of Silva et al. [33] and Blennow and Persson [34]. The questionnaire comprises two parts. The first part consists of eight questions that inquire about the demographic data of the respondent, including their sex, age, education level, monthly income, occupation, place of residence, marital status and involvement in organizations related to environmental protection or the forestry industry. This study considered the percentage of representative samples of the entire sample collection. Regarding age, only individuals aged 18 years or older are considered because respondents under that age may not be fully equipped with the ability to think independently, which could hinder the survey results [35-37].

Taiwan's forest consists of alpine tundra, subalpine coniferous forest, cold coniferous forest, temperate mountainous coniferous forest, temperate mountainous broad-leaved forest, subtropical mountainous broad-leaved forest and tropical coastal forest [38]. In this study, Taiwan is divided into 17 regions on the basis of the 22 administrative cities, considering the population of these cities (Figure 1). The 17 regions were decided according to the following measures: (1) Hsinchu County and Hsinchu City were combined; (2) Chiayi County and Chiayi City were combined; and (3) the offshore islands were omitted. The resulting 17 regions for the place of residence of respondents were: Keelung, New Taipei, Taipei, Taoyuan, Hsinchu, Miaoli, Taichung, Changhua, Nantou, Yunlin, Chiayi, Tainan, Kaohsiung, Pingtung, Yilan, Hualien and Taitung. According to the definition of National Statistics of Taiwan, an urban area is (1) an area of more than 20,000 people and (2) an area of more than 300 inhabitants per square kilometer in population density [39]. Therefore, Keelung, New Taipei, Taipei, Taoyuan, Hsinchu, Taichung, Changhua, Yunlin, Chiayi, Tainan, Kaohsiung and Yilan are classified as urban areas. In contrast, Miaoli, Nantou, Pingtung, Hualien and Taitung are classified as rural areas. Moreover, the population ratio of the latest population data announced by the Ministry of the Interior [40] was used as a reference for the proportion of questionnaires issued in each place of residence. The item concerning respondents' involvement in organizations related to environmental protection or the forestry industry was designed to determine whether such experiences affect the survey result on the awareness and experiences of climate change influences and adaptation policies. 


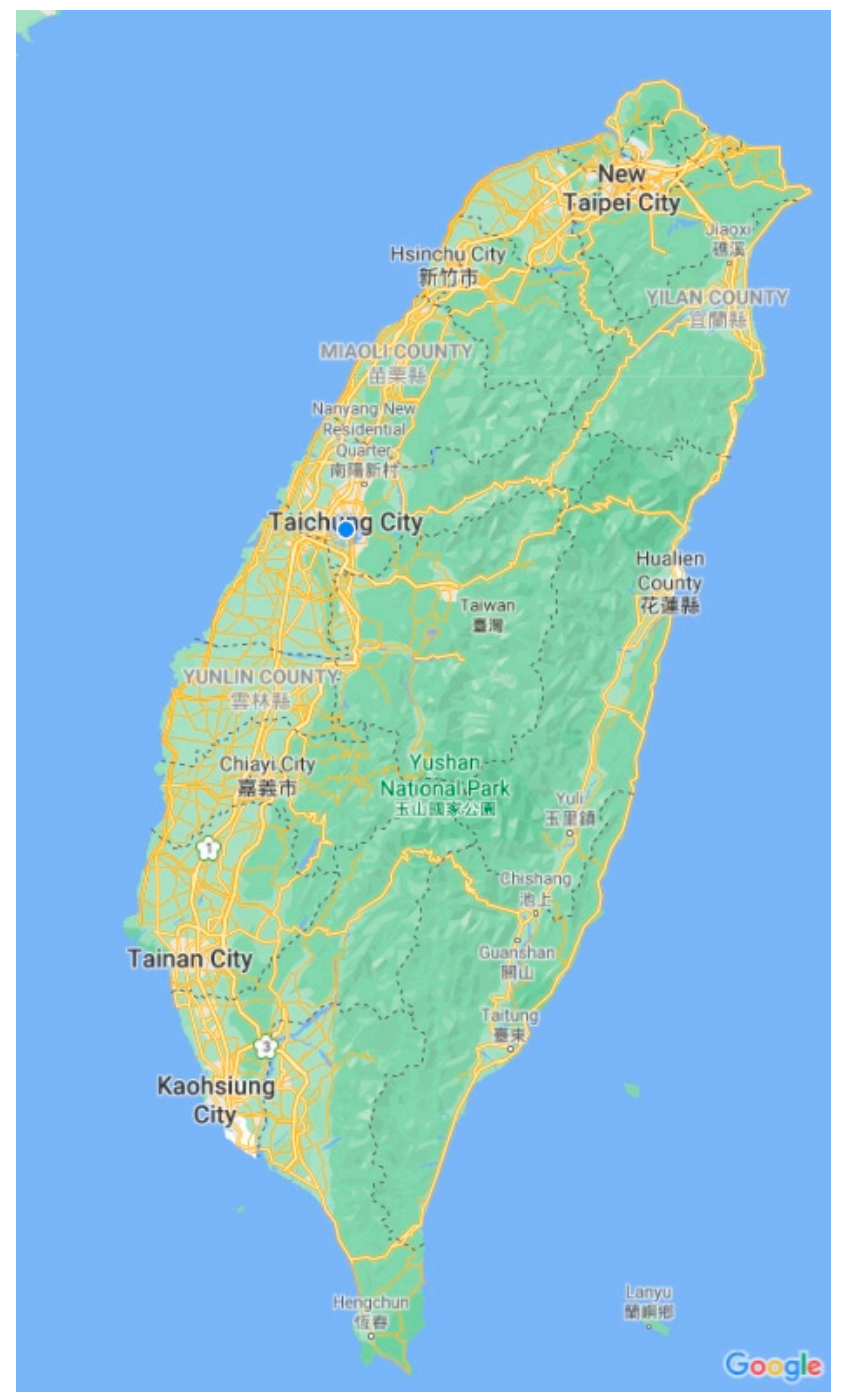

Figure 1. Study Site.

On the basis of Silva et al. [33], the second part of the questionnaire determines the awareness and experiences of respondents regarding climate change and adaptation policies. This part comprises four aspects: general awareness of climate change, experience of extreme weather events, thoughts on the potential effects and implementation of adaptation actions (Table 1). The first aspect, general awareness of climate change, refers to how respondents view climate change and their level of concern. The second aspect, experience of extreme weather events, represents the effect of climate change "felt" by the respondents. The experience of actual extreme weather events also helps reveal which type of weather event is the most common for the respondents. The third aspect, thoughts on potential effects, reveals respondents' understanding regarding the effect of climate change on forests as well as their opinions on the future changes of Taiwan's forests. The fourth aspect, implementation of adaptation actions, reveals whether respondents think adaptation policies should be proactively implemented and which operation/management policies are required for implementation. Additionally, this aspect asks about the main factor preventing Taiwanese forest owners and managers from adapting to climate change, as well as the type of help they most likely require. Since the awareness and definition of climate change and extreme weather events differ for each individual, this study did not define these terms on the questionnaire to understand the awareness of members of the public from different socioeconomic backgrounds. Nevertheless, forestry-related terms on the questionnaire were all noted to ensure that the respondents understood them. 
Table 1. Questionnaire Design.

\begin{tabular}{|c|c|c|}
\hline Aspects & Items & Reference \\
\hline \multicolumn{3}{|c|}{ General awareness of climate change } \\
\hline $\begin{array}{l}\text { 1. Do you think that climate change } \\
\text { is happening? }\end{array}$ & $\begin{array}{l}\square \text { Absolutely not. } \\
\square \text { Maybe not. } \\
\square \text { I don't know. } \\
\square \text { Maybe. } \\
\square \text { Absolutely yes. }\end{array}$ & $\begin{array}{l}\text { Wang et al. [41], } \\
\text { Blennow and Persson [34] }\end{array}$ \\
\hline 2. Do you think what causes climate change? & $\begin{array}{l}\square \text { Natural factors. } \\
\square \text { Human activities. } \\
\square \text { Human activities and natural factors. } \\
\square \text { I don't know. }\end{array}$ & \\
\hline $\begin{array}{l}\text { 3. Do you think that the forest } \\
\text { management policies must be } \\
\text { changed to adapt to climate change? }\end{array}$ & $\begin{array}{l}\square \text { Yes, forest management and operation must } \\
\text { be adjusted to adapt to climate change. } \\
\square \text { No, forests can respond to climate change } \\
\text { on their own. } \\
\square \text { I don't know. } \\
\square \text { Other. }\end{array}$ & Silva et al. [33] \\
\hline $\begin{array}{l}\text { 4. How much do you care } \\
\text { about climate change? }\end{array}$ & $\begin{array}{l}\square \text { Absolutely not. } \\
\square \text { Slightly. } \\
\square \text { A little. } \\
\square \text { A lot. } \\
\square \text { Very much. }\end{array}$ & Silva et al. [33] \\
\hline
\end{tabular}

Experience of extreme weather events

\begin{abstract}
5. Have you experienced any extreme weather event caused by climate change (e.g., sudden extreme heavy rain, floods, heatwaves or abnormal cold wave)?
\end{abstract}

6. To continue, what changes have you observed (experienced)? (You may select more than one answer) $\square$ Absolutely not.
$\square$ Maybe not.
$\square$ I don't know.
$\square$ Maybe.
$\square$ Absolutely yes.

$\square$ None.

$\square$ Heatwave.

$\square$ Cold wave.

$\square$ Drought.

$\square$ Extreme rainfall.

$\square$ Storms.

$\square$ Heavy snow.

$\square$ Early frost or late frost.

$\square$ Other.

Thoughts on the potential effects

7. Do you think that climate change will affect Taiwan's forests?

8. To continue, what changes do you expect to occur? (You may select more than one answer) $\square$ Absolutely not.
$\square$ Maybe not.
$\square$ I don't know.
$\square$ Maybe.
$\square$ Absolutely yes.

$\square$ Absolutel

$\square$ Changes in the composition of tree species.

$\square$ Increased growth speed of trees.

$\square$ Decreased growth speed of trees.

$\square$ Decreased soil fertility.

$\square$ Increased plant diseases and pests.

$\square$ Increased extreme events (e.g., drought, strong wind and forest fire).

$\square$ Deterioration in forest adaptability.

Blennow et al. [22]

Silva et al. [33],

Yousefpour and

Hanewinkel [25]

\section{Implementation of adaptation actions}

9. If you were a forest owner, would you adjust your forest management methods according to climate change or climate data?

\section{$\square$ Absolutely not.}

$\square$ Maybe not.

$\square$ I don't know.

$\square$ Maybe.

$\square$ Absolutely yes.
Blennow and Persson [34], Blennow et al. [22]

Wang et al. [41], Yousefpour and Hanewinkel [25] 
Table 1. Cont

\begin{tabular}{|c|c|c|}
\hline Aspects & Items & Reference \\
\hline $\begin{array}{l}\text { 10. To continue, if you were a forest owner, } \\
\text { what would you change at the forest } \\
\text { management level? (You may select } \\
\text { more than one answer) }\end{array}$ & $\begin{array}{l}\square \text { Nothing. } \\
\square \text { Increase the natural renewal ratio. } \\
\square \text { Plant more suitable species. } \\
\square \text { Increase the plantation of mixed forest. } \\
\square \text { Change the composition of tree species. } \\
\square \text { Cut down unnecessary tree species. } \\
\square \text { Conduct adequate thinning. } \\
\square \text { Change the frequency or intensity of thinning. } \\
\square \text { Improve lumber technology and equipment. } \\
\square \text { Change the length of rotation periods. } \\
\square \text { Reduce wood production goals. } \\
\square \text { Monitor damage (living organisms or nonliving materials). } \\
\square \text { Purchase insurance. } \\
\square \text { Other. }\end{array}$ & $\begin{array}{l}\text { Wang et al. [41], } \\
\text { Silva et al. [33], } \\
\text { Yousefpour and } \\
\text { Hanewinkel [25] }\end{array}$ \\
\hline $\begin{array}{l}\text { 11. Do you think what is the main factor for } \\
\text { why forest owners do not take adaptation } \\
\text { actions in response to climate change? }\end{array}$ & $\begin{array}{l}\square \text { Lack of technical knowledge. } \\
\square \text { Lack of government subsidy incentives. } \\
\square \text { Lack of the idea that "this is crucial". } \\
\square \text { Lack of difficulty in acquiring relevant information. } \\
\square \text { Inability to change the management level. } \\
\square \text { Other. }\end{array}$ & $\begin{array}{l}\text { Wang et al. [41], } \\
\text { Nelson et al. [8] }\end{array}$ \\
\hline $\begin{array}{l}\text { 12. In response to climate change, do } \\
\text { you think which type of help the } \\
\text { forest owners require the most? }\end{array}$ & $\begin{array}{l}\square \text { Government subsidy incentives for adaptation policies. } \\
\square \text { More technical information from the government. } \\
\square \text { Training and technical instruction from the government. } \\
\square \text { Raising awareness of climate change and understanding } \\
\text { of the importance of adaptation. } \\
\square \text { measures by the government. }\end{array}$ & Silva et al. [33] \\
\hline $\begin{array}{l}\text { 13. Overall, do you think that the current } \\
\text { policy is fit for reducing the negative } \\
\text { influences of climate change? }\end{array}$ & $\begin{array}{l}\square \text { Yes, the current policy is adequate and well implemented. } \\
\square \text { Yes, the current policy is adequate, but poorly implemented. } \\
\square \text { Yes, the current policy is adequate, but some content and } \\
\text { measures must be modified. } \\
\square \text { No, the current policy must be drastically changed. }\end{array}$ & $\begin{array}{l}\text { Wang et al. [41], } \\
\text { Nelson et al. [8], } \\
\text { Silva et al. [33] }\end{array}$ \\
\hline
\end{tabular}

The expenditure required by the government to formulate policies on climate change and forest management mainly comes from the taxation of the people across the country instead of being only from that of the forest owners. Based on the concept of democratic society, even if the people are not forest owners, analyzing the people's thoughts and attitudes can help the government to allocate forest management budgets and design the forest adaption policies.

This study used descriptive statistics to explore respondents' socioeconomic backgrounds, their awareness and experiences regarding climate change and relevant adaptation policies and their willingness to adopt adaptation actions in response to climate change. Subsequently, the Kruskal-Wallis test was applied to determine the differences in awareness and experiences of people who live in different regions. Furthermore, Spearman's correlation analysis was conducted to investigate awareness and experiences and their relationship with the adaptation intention of managers, to determine which of the aspects were critical in affecting adaptation actions.

\section{Results}

\subsection{Sample Structure}

The questionnaire was distributed in September 2018. Among the total of 650 questionnaires were distributed, 488 were valid leading to the valid response rate of $75.08 \%$. The percentages of respondents from each county and city were roughly consistent with the percentage of the Taiwanese population aged 18 years and older (Table 2). Table 3 presents the sample structure. Among the respondents, women counted slightly more $(51.2 \%)$ than men. Most respondents were aged 18-29 years (47.3\%), had an education level of university or college $(60.5 \%)$ and had a personal monthly income of NT\$20,000-50,000 $(34.4 \%)$. Regarding occupation, most were students $(28.1 \%)$, followed by military person- 
nel, civil servants and teachers (20.7\%), and service department employees (14.8\%). The majority of respondents were unmarried (63.5\%) and were not involved in organizations related to environmental protection or the forestry industry $(82.38 \%)$. In addition, this study employed an online survey method. To ensure the reliability and validity of the results, each hyperlink can only be used once, which eliminates repeated answers and ensures a consistent sample size as designed.

Table 2. Comparison between valid questionnaires and population.

\begin{tabular}{|c|c|c|c|c|c|c|}
\hline \multirow{2}{*}{\multicolumn{3}{|c|}{ Respondent Demographics }} & \multicolumn{2}{|c|}{$\begin{array}{c}\text { Population Aged } 18 \text { Years } \\
\text { and Above }\end{array}$} & \multicolumn{2}{|c|}{$\begin{array}{l}\text { Number of Samples } \\
(n=488)\end{array}$} \\
\hline & & & Population & Percentage & Sample & Percentage \\
\hline \multirow{2}{*}{\multicolumn{2}{|c|}{ Sex }} & Male & $9,848,519$ & $49.41 \%$ & 238 & $48.80 \%$ \\
\hline & & Female & $10,083,000$ & $50.59 \%$ & 250 & $51.20 \%$ \\
\hline & \multirow{12}{*}{ Urban } & Keelung & 319,684 & $1.62 \%$ & 7 & $1.43 \%$ \\
\hline & & New Taipei & $3,362,905$ & $17.06 \%$ & 84 & $17.21 \%$ \\
\hline & & Taipei & $2,235,059$ & $11.34 \%$ & 58 & $11.89 \%$ \\
\hline & & Yilan & 385,585 & $1.96 \%$ & 10 & $2.05 \%$ \\
\hline & & Taoyuan & $1,784,087$ & $9.05 \%$ & 44 & $9.02 \%$ \\
\hline & & Hsinchu & 441,485 & $2.24 \%$ & 19 & $3.89 \%$ \\
\hline & & Taichung & $2,284,339$ & $11.59 \%$ & 57 & $11.68 \%$ \\
\hline & & Changhua & $1,065,190$ & $5.41 \%$ & 25 & $5.12 \%$ \\
\hline & & Yunlin & 584,303 & $2.97 \%$ & 16 & $3.28 \%$ \\
\hline & & Chiayi & 443,127 & $2.25 \%$ & 12 & $2.46 \%$ \\
\hline & & Tainan & $1,592,901$ & $8.08 \%$ & 42 & $8.61 \%$ \\
\hline & & Kaohsiung & $2,349,834$ & $11.92 \%$ & 61 & $12.50 \%$ \\
\hline & \multirow{5}{*}{ Rural } & Miaoli & 461,733 & $2.34 \%$ & 12 & $2.46 \%$ \\
\hline & & Nantou & 427,485 & $2.17 \%$ & 12 & $2.46 \%$ \\
\hline & & Pingtung & 711,674 & $3.61 \%$ & 19 & $3.89 \%$ \\
\hline & & Hualien & 278,026 & $1.41 \%$ & 5 & $1.02 \%$ \\
\hline & & Taitung & 185,987 & $0.94 \%$ & 5 & $1.02 \%$ \\
\hline & \multicolumn{2}{|r|}{ North } & $6,861,851$ & $45.72 \%$ & 222 & $45.49 \%$ \\
\hline & \multicolumn{2}{|r|}{ Central } & $3,704,351$ & $24.48 \%$ & 122 & $25.00 \%$ \\
\hline & \multicolumn{2}{|r|}{ South } & $4,238,445$ & $30.41 \%$ & 134 & $27.46 \%$ \\
\hline & \multicolumn{2}{|r|}{ East } & 317,308 & $2.35 \%$ & 10 & $2.05 \%$ \\
\hline
\end{tabular}

According to the results, $47.34 \%$ of returned questionnaires were from respondents aged 18-29 years. This raised the question of whether the younger generation is sufficiently representative of the entire Taiwanese population. Therefore, future studies that employ a questionnaire method are advised to distribute their questionnaire through a form of media with evenly distributed age groups to prevent a similar skewness. 
Table 3. Sample Descriptive $(n=488)$.

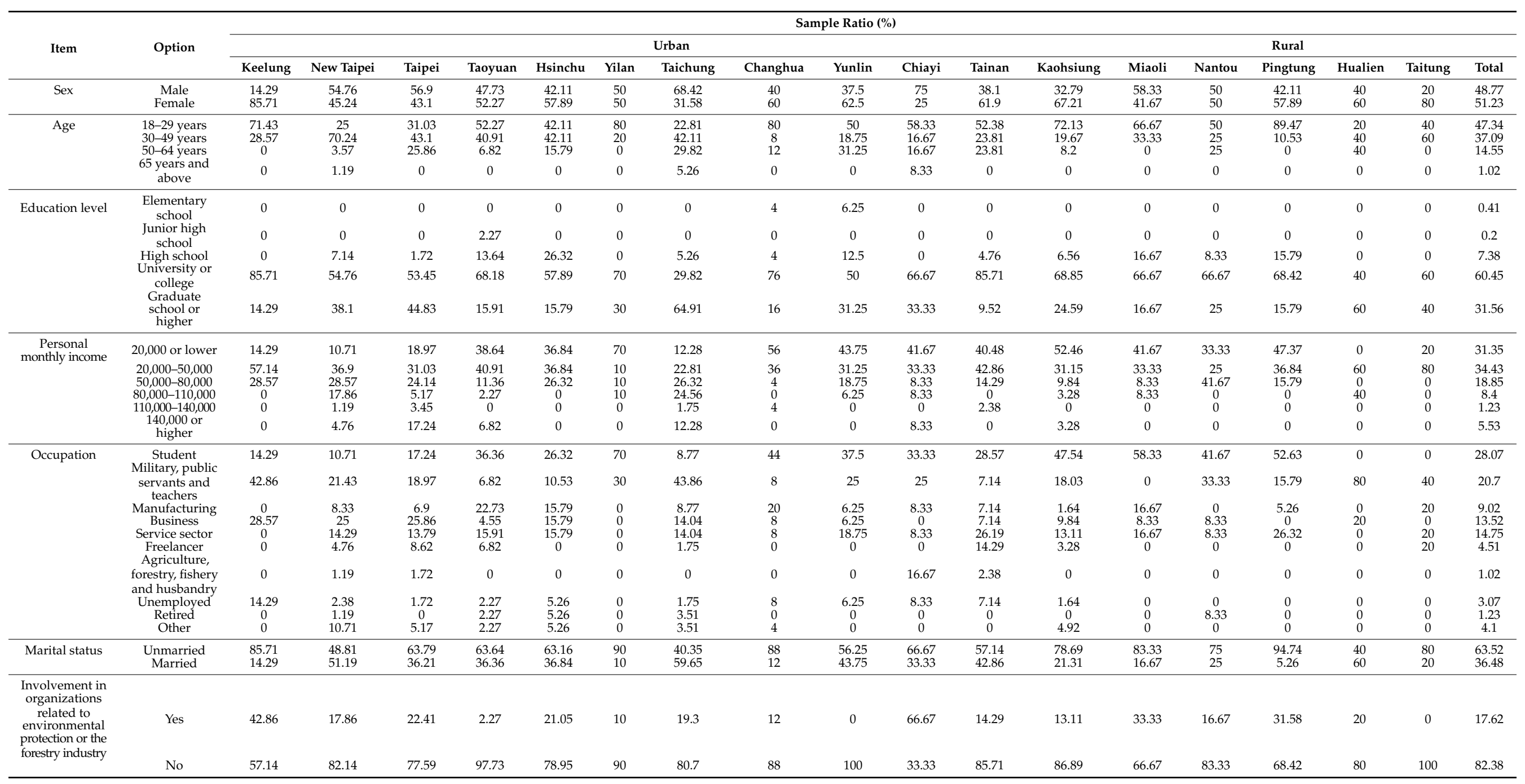




\subsection{Respondents' Thoughts on Climate Change and Adaptation Policies}

\subsubsection{Awareness of Climate Change}

The results of the first aspect, general awareness of climate change, revealed that $88.11 \%$ respondents believed climate change to be a fact (Table 4 ), which is consistent with the results of Wang et al. [41] that sampled in Taiwan. However, $1.02 \%$ thought that climate change may not be or is not real. Regarding the cause of climate change, $77.05 \%$ respondents believed climate change to be caused by human activities and natural factors, whereas $21.72 \%$ believed it only to be related to human activities. Such a result revealed that most respondents thought climate change is closely related to human activities. Regarding the level of concern toward climate change, the mean result was 3.55, falling between a little and a lot. Most respondents $(90.57 \%)$ agreed that forest management and operation must be adjusted in response to climate change. The results obtained by this study were higher in percentage in terms of the level of concern toward climate change and whether forest management and operation must be adjusted compared with a relevant study [33].

Table 4. Respondents' awareness toward climate change.

\begin{tabular}{|c|c|c|c|}
\hline Items & Options & Number of Samples & Percentage (\%) \\
\hline $\begin{array}{l}\text { 1. Do you think that } \\
\text { climate change } \\
\text { is happening? }\end{array}$ & $\begin{array}{l}\text { Absolutely not. } \\
\text { Maybe not. } \\
\text { I don't know. } \\
\text { Maybe. } \\
\text { Absolutely yes. }\end{array}$ & $\begin{array}{c}3 \\
2 \\
1 \\
52 \\
430\end{array}$ & $\begin{array}{c}0.61 \\
0.41 \\
0.20 \\
10.66 \\
88.11\end{array}$ \\
\hline $\begin{array}{l}\text { 2. Do you think what } \\
\text { causes climate change? }\end{array}$ & $\begin{array}{l}\text { Natural factors. } \\
\text { Human activities. } \\
\text { Human activities and } \\
\text { natural factors. } \\
\text { I don't know. }\end{array}$ & $\begin{array}{c}3 \\
106 \\
376 \\
3\end{array}$ & $\begin{array}{c}0.61 \\
21.72 \\
77.05 \\
0.61\end{array}$ \\
\hline $\begin{array}{l}\text { 3. Do you think that the } \\
\text { forest management } \\
\text { policies must be } \\
\text { changed to adapt } \\
\text { to climate change? }\end{array}$ & $\begin{array}{l}\text { Yes, forest management } \\
\text { and operation must be } \\
\text { adjusted to adapt to } \\
\text { climate change. } \\
\text { No, forests can respond to } \\
\text { climate change on their own. } \\
\text { I don't know. } \\
\text { Other. }\end{array}$ & $\begin{array}{c}442 \\
9 \\
32 \\
5\end{array}$ & $\begin{array}{l}90.57 \\
\\
1.84 \\
6.56 \\
1.02\end{array}$ \\
\hline $\begin{array}{l}\text { 4. How much do you } \\
\text { care about climate change? }\end{array}$ & $\begin{array}{l}\text { Absolutely not. } \\
\text { Slightly. } \\
\text { A little. } \\
\text { A lot. } \\
\text { Very much. }\end{array}$ & $\begin{array}{c}6 \\
56 \\
189 \\
139 \\
100\end{array}$ & $\begin{array}{c}1.23 \\
11.48 \\
38.73 \\
28.07 \\
20.49\end{array}$ \\
\hline
\end{tabular}

\subsubsection{Experience of Extreme Weather Events Caused by Climate Change}

The results revealed that $53.89 \%$ respondents indicated that they have experienced extreme weather events that were "caused by climate change" (Table 5), which is higher than the results obtained by Blennow et al. [22]. When we compared the responses of respondents from different counties and cities, only $28.57 \%$ of respondents from Keelung thought they had experienced extreme events, followed by $40.00 \%$ from Yilan and $42.62 \%$ from Kaohsiung. Among all extreme weather events caused by climate change, the most common were heatwaves $(49.80 \%)$, extreme rainfall $(76.43 \%)$ and storms $(59.22 \%)$, which is consistent with the results obtained by Silva et al. (2018) as well as that constitute Taiwan's increasing extreme weather [42]. Furthermore, the least experienced extreme weather events were heavy snow $(7.38 \%)$ and early or late frost $(10.04 \%)$, which are rare in the subtropical climate of Taiwan.

According to the IPCC's [13] fifth assessment report of the second working group, extreme temperature, extreme rainfall and disastrous tropical cyclones are driving factors for extreme weather in the tropical and subtropical climate zones. These three factors are strongly correlated to natural disasters in Taiwan, namely drought, extremely heavy rain and typhoons [43]. The increased frequency and intensity of extreme weather events 
have worsened top-three disaster types in Taiwan, namely floods, drought and landslide events [44].

Table 5. Respondents' experience of extreme weather events caused by climate change.

\begin{tabular}{|c|c|c|c|}
\hline Items & Options & Number of Samples & Percentage (\%) \\
\hline $\begin{array}{l}\text { 5. Have you experienced any } \\
\text { extreme weather event caused } \\
\text { by climate change (e.g., sudden } \\
\text { extreme heavy rain, floods, } \\
\text { heatwaves or abnormal cold wave)? }\end{array}$ & $\begin{array}{l}\text { Absolutely not. } \\
\text { Maybe not. } \\
\text { I don't know. } \\
\text { Maybe. } \\
\text { Absolutely yes. }\end{array}$ & $\begin{array}{c}7 \\
17 \\
12 \\
189 \\
263\end{array}$ & $\begin{array}{c}1.43 \\
3.48 \\
2.46 \\
38.73 \\
53.89\end{array}$ \\
\hline $\begin{array}{l}\text { 6. To continue, what changes have } \\
\text { you observed (experienced)? (You } \\
\text { may select more than one answer) }\end{array}$ & $\begin{array}{c}\text { None. } \\
\text { Heatwave. } \\
\text { Cold wave. } \\
\text { Drought. } \\
\text { Extreme rainfall. } \\
\text { Storms. } \\
\text { Heavy snow. } \\
\text { Early or late frost. } \\
\text { Other. }\end{array}$ & $\begin{array}{c}16 \\
243 \\
182 \\
149 \\
373 \\
289 \\
36 \\
49 \\
9\end{array}$ & $\begin{array}{c}3.28 \\
49.80 \\
37.30 \\
30.53 \\
76.43 \\
59.22 \\
7.38 \\
10.04 \\
1.84\end{array}$ \\
\hline
\end{tabular}

\subsubsection{Potential Effects of Climate Change on Forests}

Table 6 presents how respondents thought climate change may affect forests. Among all respondents, $68.65 \%$ thought that climate change will definitely affect Taiwan's forests. Regarding actual changes caused by climate change to Taiwan's forests, $84.84 \%$ respondents thought that extreme weather events will increase, $58.61 \%$ thought the composition of tree species will change and $53.48 \%$ thought that forest adaptability will deteriorate. These results were similar to those obtained by Yousefpour and Hanewinkel [25]. Among all possible changes climate change may cause to forests, only $13.73 \%$ respondents selected an increase in the growth speed of trees. Moreover, the percentage of respondents selecting this option was low in each county and city; the highest was in Nantou (33.33\%), which this study speculated was because Nantou County is situated at a higher altitude, and an increased growth rate caused by global warming would be more noticeable here than in the lowlands. The growth rate of forests is affected by the rate of glucose production, and the rate of glucose in the biosynthesis process is usually limited by low temperatures [45-48].

Table 6. Respondents' thoughts on the potential effects of climate change on forests.

\begin{tabular}{lccc}
\hline Items & Options & Number of Samples & Percentage (\%) \\
\hline \multirow{3}{*}{$\begin{array}{l}\text { 7. Do you think that } \\
\text { climate change will } \\
\text { affect Taiwan's forests? }\end{array}$} & Absolutely not. & 1 & 0.20 \\
& Maybe not. & 0 & 0 \\
& I don't know. & 4 & 0.82 \\
& Maybe. & 148 & 30.33 \\
& Absolutely yes. & 335 & 68.65 \\
\hline & Changes in the composition & 3 & 0.61 \\
8. To continue, what & of tree species. & 286 & 58.61 \\
changes do you & Increased growth speed of trees. & 67 & 13.73 \\
expect to occur? & Decreased growth & 242 & 49.59 \\
than may select more & speed of trees. & 224 & 45.90 \\
& Decreased soil fertility. & 258 & 52.87 \\
& Increased plant & & \\
& diseases and pests. & 414 & 84.84 \\
\hline & Increased extreme events & & \\
\hline & (e.g., drought, strong & 261 & 53.48 \\
\hline
\end{tabular}

\subsubsection{Forest Adaptation Policies}

According to the research results (Table 7), only $46.93 \%$ respondents would adjust their management according to climate change or climate information if they were forest 
owners. Many respondents $(70.29 \%)$ selected that they would adopt an adaptation policy of monitoring damage, followed by adequate thinning (57.38\%) and planting more suitable tree species (55.12\%). Therefore, different to the results obtained by Wang et al. [41], the Taiwanese public surveyed selected to adapt by monitoring damage, which currently falls under the responsibility of the government or other administrative authority.

Table 7. Respondents' thoughts on the implementation of forest adaptation measures and current policies.

\begin{tabular}{|c|c|c|c|}
\hline Items & Options & Number of Samples & Percentage $(\%)$ \\
\hline \multirow{5}{*}{$\begin{array}{l}\text { 9. If you were a forest owner, would } \\
\text { you adjust your forest management } \\
\text { methods according to climate change } \\
\text { or climate data? }\end{array}$} & Absolutely not. & 2 & 0.41 \\
\hline & Maybe not. & 7 & 1.43 \\
\hline & I don't know. & 30 & 6.15 \\
\hline & Maybe. & 208 & 42.62 \\
\hline & Absolutely yes. & 229 & 46.93 \\
\hline \multirow{14}{*}{$\begin{array}{l}\text { 10. To continue, if you were a forest } \\
\text { owner, what would you change at the } \\
\text { forest management level? (You may } \\
\text { select more than one answer) }\end{array}$} & Nothing. & 14 & 2.87 \\
\hline & Increase the natural renewal ratio. & 150 & 30.74 \\
\hline & Plant more suitable species. & 269 & 55.12 \\
\hline & Increase the plantation of mixed forest. & 222 & 45.49 \\
\hline & Change the composition of tree species. & 144 & 29.51 \\
\hline & Cut down unnecessary tree species. & 83 & 17.01 \\
\hline & Conduct adequate thinning. & 280 & 57.38 \\
\hline & Change the frequency or intensity of thinning. & 180 & 36.89 \\
\hline & Improve lumber technology and equipment. & 125 & 25.61 \\
\hline & Change the length of rotation periods. & 129 & 26.43 \\
\hline & Reduce wood production goals. & 126 & 25.82 \\
\hline & $\begin{array}{l}\text { Monitor damage (living organisms } \\
\text { or nonliving materials). }\end{array}$ & 343 & 70.29 \\
\hline & Purchase insurance. & 93 & 19.06 \\
\hline & Other. & 9 & 1.84 \\
\hline \multirow{6}{*}{$\begin{array}{l}\text { 11. Do you think what the main } \\
\text { factors for why forest owners do } \\
\text { not take adaptation actions in } \\
\text { response to climate change? }\end{array}$} & Lack of technical knowledge. & 46 & 9.43 \\
\hline & Lack of government subsidy incentives. & 101 & 20.70 \\
\hline & Lack of the idea that "this is crucial". & 167 & 34.22 \\
\hline & $\begin{array}{l}\text { Lack of difficulty in acquiring } \\
\text { relevant information. }\end{array}$ & 37 & 7.58 \\
\hline & Inability to change the management level. & 135 & 27.66 \\
\hline & Other. & 2 & 0.41 \\
\hline \multirow{4}{*}{$\begin{array}{l}\text { 12. In response to climate change, } \\
\text { do you think which type of help } \\
\text { the forest owners require the most? }\end{array}$} & $\begin{array}{l}\text { Government subsidy incentives } \\
\text { for adaptation policies. }\end{array}$ & 174 & 35.66 \\
\hline & More technical information from the government. & 34 & 6.97 \\
\hline & $\begin{array}{l}\text { Training and technical instruction } \\
\text { from the government. }\end{array}$ & 71 & 14.55 \\
\hline & $\begin{array}{l}\text { Raising awareness of climate change and } \\
\text { understanding of the importance of adaptation } \\
\text { measures by the government. }\end{array}$ & 201 & 42.83 \\
\hline \multirow{4}{*}{$\begin{array}{l}\text { 13. Overall, do you think that the } \\
\text { current policy is fit for reducing the } \\
\text { negative influences of climate change? }\end{array}$} & $\begin{array}{l}\text { Yes, the current policy is adequate } \\
\text { and well implemented. }\end{array}$ & 8 & 1.64 \\
\hline & $\begin{array}{l}\text { Yes, the current policy is adequate, } \\
\text { but poorly implemented. }\end{array}$ & 80 & 16.39 \\
\hline & $\begin{array}{l}\text { Yes, the current policy is adequate, but some } \\
\text { content and measures must be modified. }\end{array}$ & 171 & 35.04 \\
\hline & $\begin{array}{l}\text { No, the current policy must be } \\
\text { drastically changed. }\end{array}$ & 229 & 46.93 \\
\hline
\end{tabular}

Most respondents considered that too few forest owners thinking that "this is crucial" to be the key factor for the lack of adaptation actions (34.22\%), followed by their inability to change the level of management $(27.66 \%)$. To remove obstacles to implementing adaptation policies, most respondents proposed that the government should raise awareness among forest owners concerning climate change and adaptation policies (42.83\%), followed by 
the proposal that the government should implement policies accompanied by subsidy incentives $(27.66 \%)$. Most respondents thought that current policies must be drastically changed or modified. Moreover, most respondents revealed that they knew considerably little about climate change and possible adaptation plans, which is consistent with relevant studies from Germany [25], Sweden [49] and other regions [50]; this suggests that public education on climate change still has room to improve worldwide.

Despite most respondents indicating they knew little about climate change and adaptation plans, they were willing to implement relevant adaptation policies. For example, more than half selected planting more suitable trees or species capable of constantly adapting to climate change (55.12\%); however, no studies have specifically indicated which species can do so, and therefore, current information is insufficient to guarantee the effectiveness of such actions. Relevant studies have revealed similar results; for example, Silva et al. [33] indicated that information on recommended species may help forest owners to adapt to climate change. Therefore, new knowledge must be acquired to facilitate decision-making in forest operation in the future, such as that on adaptable species and which trees can be used for afforestation [51,52].

Finally, the success of adaptation policies lies in stakeholders participating in discussions and proposing initiatives [31]. Comprehensive stakeholder participation assists developing common values and objectives, improves the forestry division and encourages public and private participation. In addition, such participation grants forest managers the flexibility to select and implement measures that meet specific demands and local situations.

Next, to determine the public's awareness of climate change and forest management adaptation and its correlation with the implementation of forest adaptation policies, we set a five-point scale as the ordinal variable by following Silva et al. [33]. Spearman's correlation analysis was conducted on the four aspects, namely the general awareness of climate change, experience of extreme weather events, thoughts on potential effects of climate change on forests and implementation of adaptation actions. According to the results (Table 8), although the relationship between awareness of climate change and implementation of adaptation actions was significant, the correlation level was low ( $\mathrm{r} 2=0.168$, $p<0.001)$. Similar results were observed between thoughts on the potential effects of climate change on forests and the implementation of adaptation actions $(\mathrm{r} 2=0.237, p<0.001)$. However, the correlations between experience of extreme weather events and the other three aspects all reached a medium level (approximately 0.3-0.7), which means the personal experiences of respondents were considerably influential on their choice of adaptation actions.

Table 8. Results of Spearman's correlation analysis on the four aspects.

\begin{tabular}{|c|c|c|c|c|c|}
\hline \multicolumn{2}{|l|}{ Aspects } & $\begin{array}{l}\text { General Awareness } \\
\text { of Climate Change }\end{array}$ & $\begin{array}{c}\text { Thoughts on } \\
\text { Potential Effects }\end{array}$ & $\begin{array}{l}\text { Experience of Extreme } \\
\text { Weather Events }\end{array}$ & $\begin{array}{l}\text { Implementation of } \\
\text { Adaptation Actions }\end{array}$ \\
\hline $\begin{array}{l}\text { General awareness } \\
\text { of climate change }\end{array}$ & $\begin{array}{l}\text { Correlation } \\
\text { coefficient }\end{array}$ & 1.000 & $0.213^{* * *}$ & $0.337^{* * *}$ & $0.168^{* * *}$ \\
\hline $\begin{array}{c}\text { Thoughts on } \\
\text { potential effects }\end{array}$ & $\begin{array}{l}\text { Correlation } \\
\text { coefficient }\end{array}$ & & 1.000 & $0.300^{* * *}$ & $0.237^{* * *}$ \\
\hline $\begin{array}{l}\text { Experience of extreme } \\
\text { weather events }\end{array}$ & $\begin{array}{l}\text { Correlation } \\
\text { coefficient }\end{array}$ & & & 1.000 & $0.374^{* * *}$ \\
\hline $\begin{array}{l}\text { Implementation of } \\
\text { adaptation actions }\end{array}$ & $\begin{array}{l}\text { Correlation } \\
\text { coefficient }\end{array}$ & & & & 1.000 \\
\hline
\end{tabular}

Note: ${ }^{* * *} p<0.001$.

The results were consistent with relevant studies in that an individual's awareness of climate change does not necessarily lead to further adaptation actions [53]. However, personal experiences of extreme weather events caused by climate change were critical in the choice of adaptation actions [54-56] and this tendency appears to be valid in Taiwan, as well. 


\section{Discussion}

To determine the effect of respondents' place of residence on their awareness and experiences regarding climate change and adaptation policies, this study categorized all respondents into 17 regions. The results revealed a difference between the support of adaptation policies and actual actions.

Among all respondents, 91\% supported the implementation of adaptation policies in forest management in response to climate change (Figure 2). However, the support dropped to $47 \%$ when the respondents imagined if they were forest owners (Figure 3). Furthermore, in each county and city, more than $80 \%$ respondents supported the implementation of adaptation policies, and the support drastically dropped when they imagined if they were forest owners. Support dropped the most in Changhua (28\%) and Nantou (25\%), whereas that in Hsinchu (74\%) and Chiayi (67\%) remained high.

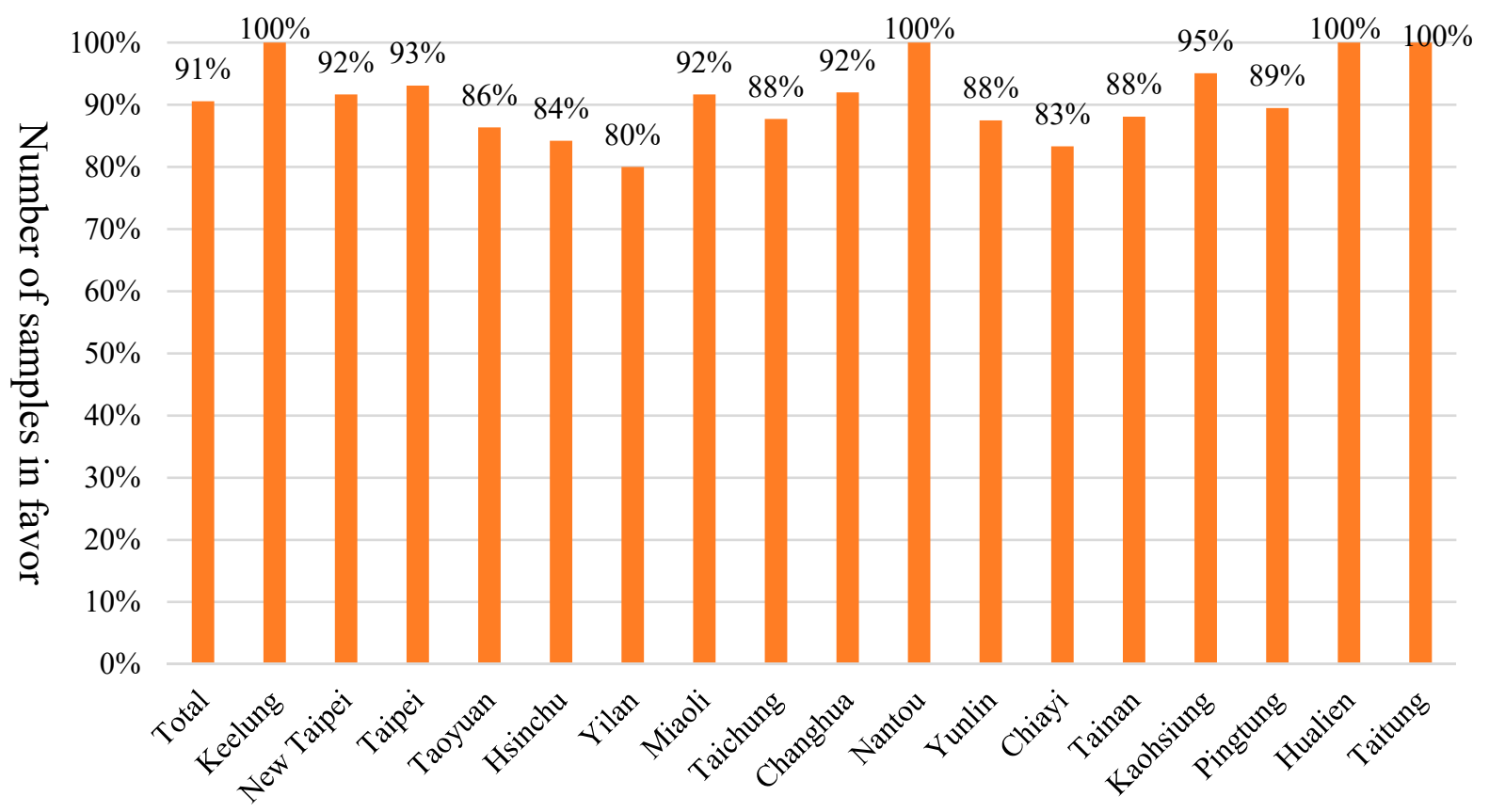

Figure 2. Supporting ratio of adaptation policies in response to climate change in each county/city in Taiwan (question 3).

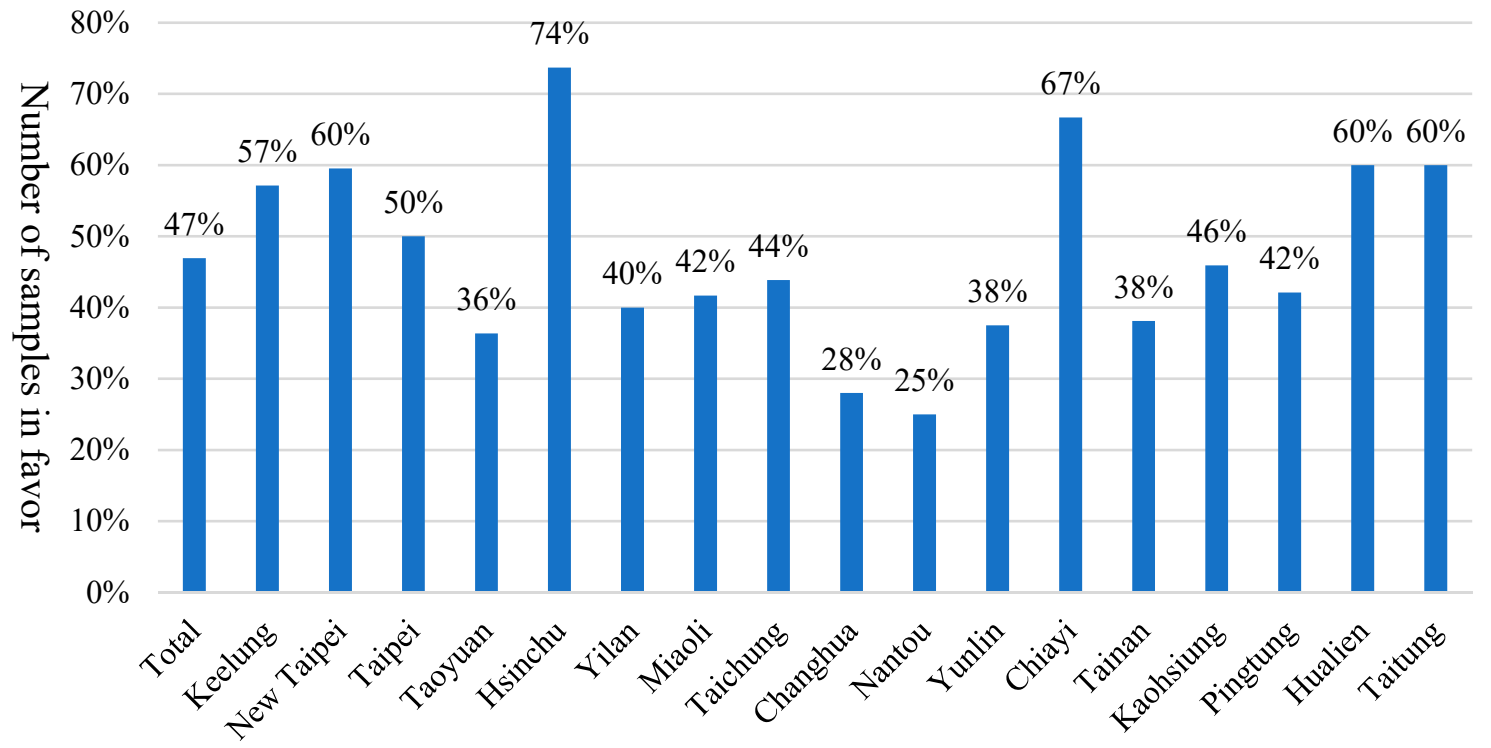

Figure 3. Supporting ratio of adaptation policies in response to climate change when the respondents imagined that they were forest owners (question 9). 
A study on British forest planners determined that the uncertainty of climate change was a critical reason behind the forestry industry's adaptation to climate change [57]. Comparing Figure 2 with Figure 3, the results of this study suggest that when people imagine that they were forest owners, they will further consider forestry income rather than simply considering climate change and environmental factors. It is speculated that such results may be related to the fact that numerous uncertain factors (e.g., cost and economy) must be considered in forest management decision-making [30,58,59].

This study explored whether the respondents' characteristics (gender, age and residential regions) affect their perception on the four dimensions (general awareness of climate change, experience of extreme weather events, thoughts on potential effects and implementation of adaptation actions). The analysis of variance shows that gender and age have no significant effect ( $p$ value $>0.05$ ). Next, we determined the differences between all four aspects among the respondents from different places of residence. First, respondent samples were divided into north, central, south and east to be compared with the results of the total sample (Table 9). The results of respondents from the east were higher than the mean value in all four aspects, whereas for respondents from the central region, the results of all aspects were lower than the mean value except for experience of extreme weather events. Next, the samples were further divided into 17 counties or cities. The Kruskal-Wallis test was conducted, which revealed no remarkable differences between these 17 counties or cities (Table 10). The results for the first aspect revealed that respondents from all counties and cities were highly aware of climate change. In the east region, Yilan, Hualien and Taitung all scored the highest of $100 \%$. These three eastern counties have the highest forest coverage rates in Taiwan. By contrast, Keelung (71.43\%), Miaoli $(75.00 \%)$ and Yunlin $(75.00 \%)$ scored the lowest in this aspect, although the difference was not remarkable.

Table 9. Differences in the awareness and experience of climate change and adaptation actions of respondents from the north, central, south and east regions.

\begin{tabular}{cccccc}
\hline & North & Central & South & East & Total \\
\hline $\begin{array}{c}\text { General awareness of } \\
\text { climate change (\%) }\end{array}$ & 89.19 & 83.61 & 89.55 & 100.00 & 88.11 \\
$\begin{array}{c}\text { Experience of extreme } \\
\text { weather events (\%) } \\
\quad \text { Thoughts on }\end{array}$ & 53.60 & 54.92 & 52.99 & 60.00 & 53.89 \\
$\begin{array}{c}\text { potential effects (\%) } \\
\text { Implementation of } \\
\text { adaptation actions (\%) }\end{array}$ & 71.62 & 62.30 & 68.66 & 80.00 & 68.65 \\
\hline
\end{tabular}

Regarding the second aspect, experience of extreme weather events caused by climate change, $53.89 \%$ of all respondents specifically indicated that they had personally experienced such events. This result indicated that Taiwan being ranked seventh on the Global Climate Risk Index is valid, for weather extremes clearly affect all lives in Taiwan. Regardless, the perception of extreme weather events differed between respondents from different counties and cities. In Nantou, Tainan, Hualien and Taitung, more than $60 \%$ of respondents indicated that they had experienced extreme weather events. In addition, respondents from these four counties and cities agreed that of all the possible influences of climate change on Taiwan's forests, the change in composition of tree species will occur. Respondents from Nantou, Hualien and Taitung, which are regions with high rates of forest coverage, agreed on the increase of extreme events; by contrast, only $66.67 \%$ of respondents in Tainan agreed on this option, which was the third lowest of all regions (the mean value of the total was $84.84 \%$ ). Among the counties and cities where the perception of extreme weather events was low, only $28.57 \%$ of respondents from Keelung answered that they had experienced extreme weather events and $57.14 \%$ indicated that they possibly had experienced such events. The second lowest perception of extreme events was observed 
for Yilan (40\%), followed by Kaohsiung (42.62\%), which are known for their relatively persistent climate with a distinct wet/dry season.

Table 10. Differences in the awareness and experiences of climate change and adaptation actions of respondents from different places of residence.

\begin{tabular}{|c|c|c|c|c|c|}
\hline & & $\begin{array}{c}\text { General } \\
\text { Awareness } \\
\text { of Climate } \\
\text { Change }(\%)\end{array}$ & $\begin{array}{l}\text { Experience } \\
\text { of Extreme } \\
\text { Weather } \\
\text { Events }(\%)\end{array}$ & $\begin{array}{c}\text { Thoughts on } \\
\text { Potential } \\
\text { Effects (\%) }\end{array}$ & $\begin{array}{l}\text { Implementation } \\
\text { of Adaptation } \\
\text { Actions (\%) }\end{array}$ \\
\hline & Total & 88.11 & 53.89 & 68.65 & 46.93 \\
\hline \multirow{12}{*}{ Urban } & Keelung & 71.43 & 28.57 & 71.43 & 57.14 \\
\hline & New Taipei & 88.1 & 55.95 & 72.62 & 59.52 \\
\hline & Taipei & 89.66 & 55.17 & 81.03 & 50 \\
\hline & Taoyuan & 88.64 & 54.55 & 56.82 & 36.36 \\
\hline & Hsinchu & 94.74 & 52.63 & 78.95 & 73.68 \\
\hline & Yilan & 100 & 40 & 60 & 40 \\
\hline & Taichung & 84.21 & 57.89 & 59.65 & 43.86 \\
\hline & Changhua & 88 & 48 & 72 & 28 \\
\hline & Yunlin & 75 & 50 & 56.25 & 37.5 \\
\hline & Chiayi & 91.67 & 50 & 66.67 & 66.67 \\
\hline & Tainan & 90.48 & 66.67 & 71.43 & 38.1 \\
\hline & Kaohsiung & 88.52 & 42.62 & 65.57 & 45.9 \\
\hline \multirow{5}{*}{ Rural } & Miaoli & 75 & 50 & 50 & 41.67 \\
\hline & Nantou & 91.67 & 66.67 & 75 & 25 \\
\hline & Pingtung & 89.47 & 57.89 & 73.68 & 42.11 \\
\hline & Hualien & 100 & 60 & 60 & 60 \\
\hline & Taitung & 100 & 60 & 100 & 60 \\
\hline & $p$ value & 0.772 & 0.748 & 0.397 & 0.135 \\
\hline
\end{tabular}

Regarding the potential effects of climate change on Taiwan's forests, the highest percentages of positive responses were observed in Taipei (81.03\%), Hsinchu $(78.95 \%)$ and Taitung $(100 \%)$. Of all the possible effects, respondents in Taipei scored low on decreased soil fertility and deterioration of forest adaptability; respondents in Taitung also scored low on deterioration of forest adaptability. The lowest percentages were observed in Taoyuan (56.82\%), Miaoli (50\%), Taichung (59.65\%) and Yunlin (56.25\%). Geographically, all four counties and cities are in the north and central regions of the western Taiwan. The results from respondents in Miaoli were remarkably lower than those of other counties and cities in terms of increased growth speed of trees, decreased growth speed of trees and increased extreme weather events.

Regarding the aspect of adaptation actions, this study revealed that counties and cities with percentages of support from respondents below the mean value were those with greater rural areas, such as Taoyuan (36.36\%), Changhua (28\%), Yunlin (37.5\%) and Tainan $(38.10 \%)$. Moreover, the results revealed that although respondents from Changhua and Nantou scored high on awareness of climate change, their support for adaptation actions was low. This observation is consistent with a relevant study; Lin [60] indicated that the information gap in rural areas was the main reason for the relatively low awareness of climate change among people who live there. Moreover, awareness of climate change in rural areas is mainly based on the people's experiences of disasters, which has resulted in low awareness of climate change tendencies and impacts that they have not yet experienced. Therefore, implementing and communicating adaptation strategies with such groups of the public is relatively difficult [43].

Climate change also notably enhanced the vulnerability and risk of rural residential areas in the face of disasters. For example, rural areas on the coast, in lowlands and on hillsides are highly vulnerable areas $[61,62]$ where the residential environment is subject to direct impacts from climate change-related disasters. Furthermore, the stability of their economic income and the obtainability of water resources are greatly affected by climate change. The resilience of rural areas in the face of a disaster has become a crucial topic. Since infrastructure in rural areas is in poor condition and the population and social structure are vulnerable, measures to enhance their adaptability in a disaster are critical. 
Next, a Venn Diagram was created according to the differences in the results of the four aspects from respondents from different places of residence (Figure 4). It revealed that Nantou exhibited results higher than average in the opinion of potential effects and experiences of extreme weather events, but the lowest of all regions in the implementation of adaptation actions; Changhua scored the second lowest result in the implementation of adaptation actions among all regions.

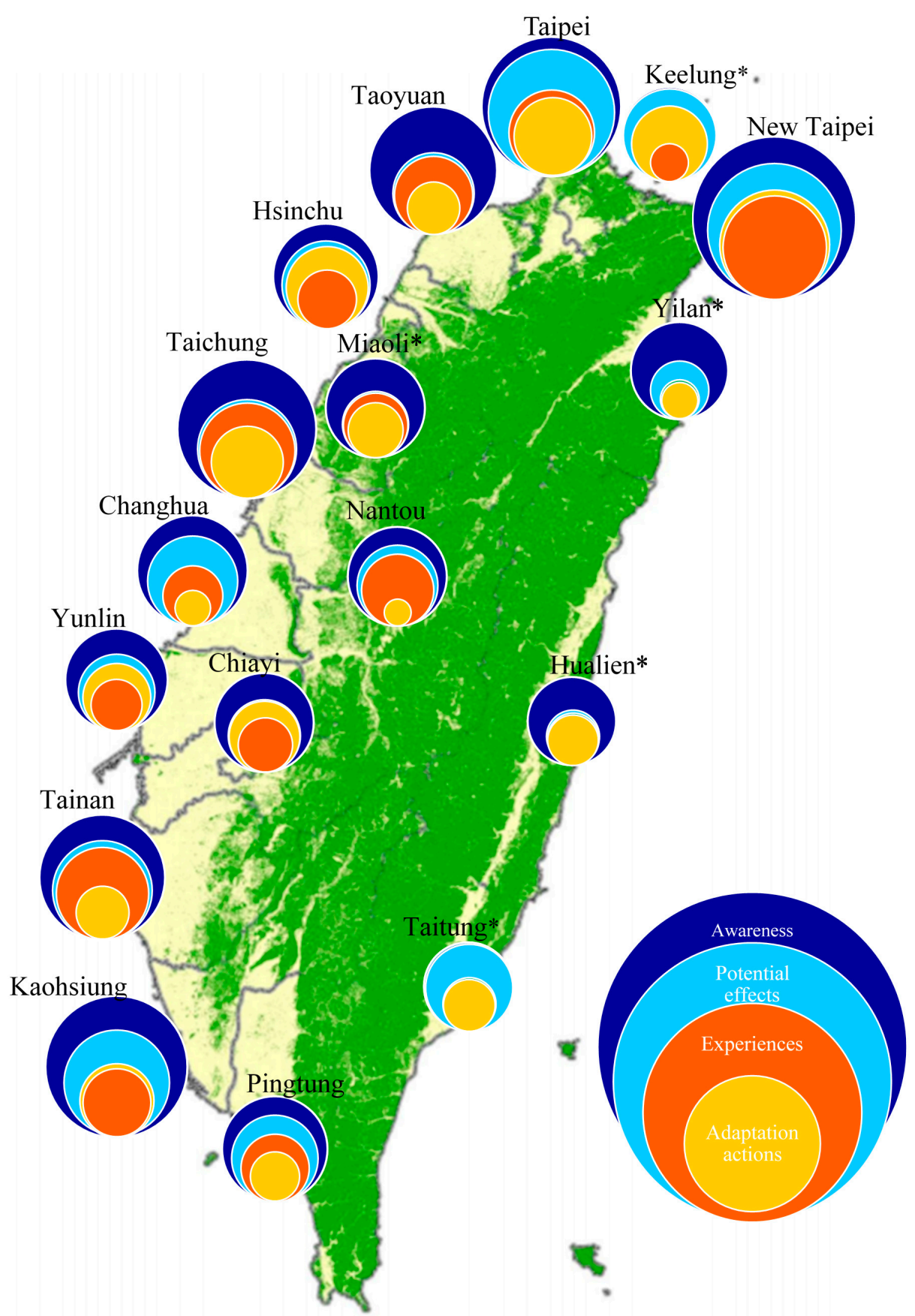

Figure 4. Venn diagram. Note 1: A Venn diagram is a diagram used to represent sets or classes (in a slightly loose sense) in the mathematical field of set theory (or theory of classes). This diagram is used to demonstrate the mathematical or logical connections between collections of objects or sets. This diagram is particularly suitable for presenting approximate relationships between sets or classes, or for being used to conduct derivation (or understanding the derivation of) the rules of set or class operations. Note 2: The size of the Venn diagram is positively related to the sample size of each county or city; the area of the circle is positively related to the number of samples. Note 3: * means the Venn diagram was finely adjusted for clarity and is not a true representation of the percentage of samples. 
This study observed an intriguing phenomenon. The lowest scores in experience of extreme weather events were observed in Keelung, Yilan and Kaohsiung. Additionally, in Keelung, New Taipei, Hsinchu, Yunlin, Chiayi and Kaohsiung, the results of the implementation of adaptation actions were all lower than those of the experience of extreme weather events. These counties and cities are also regions where natural disasters and extreme weather events have occurred with the highest frequency and number of times in Taiwan over the years. For example, the most extreme rainfall events have occurred in Yilan, Hualien, Yunlin, Chiayi, Tainan, Kaohsiung and the mountainous area of Pingtung; floods are most common on the southwestern coastal plains and Yilan; and droughts are most common in Taoyuan, Hsinchu, Chiayi, Tainan and Kaohsiung [63]. The respondents from these regions scored extremely or relatively low on the experience of extreme weather events because they do not associate such events with climate change or because they are used to these events.

Regarding the rural-urban difference, although almost $80 \%$ Taiwanese population lives in urban areas, previous urban land planning and management systems have fallen short in the aspect of climate change. Adaptation policies for climate change must be proactively implemented to improve the adaptability of urban areas. In addition, Lin et al. [64] indicated that the urban heat islands of Hsinchu, Tainan and Kaohsiung are remarkably different during the daytime and nighttime; Lin also indicated that the building coverage ratio, density of water areas and green coverage ratio help in reducing temperatures. That is, urban land use has concrete and critical influences on the temperature in urban areas. Urban space planning is a substantial strategy to respond to climate change; it provides a mechanism that affects land use and overall strategic development to respond to the threat of climate change. Hsinchu, Tainan and Kaohsiung are advised to incorporate more urban forests and parks into their overall planning to raise their green coverage ratios and reduce the heat island effect.

\section{Conclusions and Suggestions}

The objective of this study was to determine what Taiwanese people think about climate change and forest adaptation policies using a questionnaire survey and subsequent data analysis. The results revealed that most respondents believed climate change to be a fact $(88.11 \%)$ and their level of concern ranged between a little and a lot. Among all extreme weather events caused by climate change experienced by the respondents, heatwaves, extreme rainfall and storms accounted for the majority. The respondents believed that Taiwan's forests will be affected by climate change, and most thought that extreme weather events will increase (e.g., drought, strong winds and forest fire). However, this study also revealed that respondents' level of awareness of climate change has not convinced them enough to act.

According to our results, the integration of forest adaptation policies requires the public's participation, and the public's awareness of climate change greatly affects their support for relevant policies on adapting to and reducing the influence of climate change. Taiwan's forests play a critical role in managing climate change. Forestry departments may have remarkably contributed to establishing and implementing forest adaptation policies; these departments, the government and the public have their own perspective and viewpoint. Most respondents thought that the greatest obstacle to forest owners implementing adaptation policies was that they do not think such measures are crucial. Removing this obstacle requires the government to raise awareness of forests and climate change. Furthermore, most people thought that the current policy must be changed to adapt to the influence of climate change. Numerous respondents indicated that they were not aware of the government's current forest adaptation policy, suggesting that the need for the forestry section in Taiwan to promote relevant information and policies on adaptation policies, including how to achieve the objectives. Enhancing people's comprehension of current forestry policies would mitigate the gap between the public and the government to maximize the benefits the implementation of policies. Since the situation in each county 
could be different, forestry authorities must establish national forest adaptation policies and actions according to their specific needs.

This study revealed that people's experience of extreme weather events and natural disasters had the highest correlation with the implementation of adaptation actions. This indicated that experience of extreme weather events is critical for such implementation. Therefore, future studies on climate change and adaptation are advised to incorporate a section on the details of awareness and experience of natural disasters and extreme weather events to conduct a more in-depth discussion on the relationship or causal relationship between experience of extreme weather events and adaptation actions.

\section{Research Limitations}

A number of factors could influence the public's perception of adaptation actions, including gender, age, education level, living area, income level and so on. This study mainly analyzes the views of the people in different geographical regions of Taiwan on climate change and forest carbon management policies so that the government can formulate the regional climate change policies based on different regions and people's views, and the future study can analyze the impacts of the public's socioeconomic background variables such as age, marriage and gender, etc.

Author Contributions: Three co-authors contributed to the completion of this article together. W.-Y.L. was the first author and contributed to conceptualizing the research framework, data analysis, the results and conclusions and draft reviewing and editing; C.-C.W. mainly contributed to the conduction of research investigation, data analysis and results and conclusions; S.-Y.S.W. acted as a corresponding author on their behalf throughout the review, editing and sub-mission process. All authors have read and agreed to the published version of the manuscript.

Funding: This research was funded by Taiwan Ministry of Science and Technology, Reference No. MOST 108-2410-H-005-045-MY2 and MOST 110-2321-B-005 -003. S.-Y.S.W. is supported by the iPACE foundation and NSF NRT Grant 1633756.

Institutional Review Board Statement: Not applicable.

Informed Consent Statement: Not applicable.

Data Availability Statement: The data presented in this study are available on request from the corresponding author. The data are not publicly available due to private reasons.

Conflicts of Interest: The authors declare no conflict of interest. The funders had no role in the design of the study; in the collection, analyses or interpretation of data; in the writing of the manuscript or in the decision to publish the results.

\section{References}

1. Bergh, J.; Freeman, M.; Sigurdsson, B.; Kellomäki, S.; Laitinen, K.; Niinistö, S.; Peltola, H.; Linder, S. Modelling the short-term effects of climate change on the productivity of selected tree species in Nordic countries. For. Ecol. Manag. 2003, 183, 327-340. [CrossRef]

2. Jump, A.S.; Hunt, J.M.; Peñuelas, J. Rapid climate change-related growth decline at the southern range edge of Fagus sylvatica. Global Chang. Biol. 2006, 12, 2163-2174. [CrossRef]

3. Allen, C.D.; Macalady, A.K.; Chenchouni, H.; Bachelet, D.; McDowell, N.; Vennetier, M.; Kitzberger, T.; Rigling, A.; Breshears, D.D.; Hogg, E.H.; et al. A global overview of drought and heat-induced tree mortality reveals emerging climate change risks for forests. For. Ecol. Manag. 2010, 259, 660-684. [CrossRef]

4. Kurz, W.A.; Dymond, C.C.; Stinson, G.; Rampley, G.J.; Neilson, E.T.; Carroll, A.L.; Ebata, T.; Safranyik, L. Mountain pine beetle and forest carbon feedback to climate change. Nature 2008, 452, 987-990. [CrossRef] [PubMed]

5. Dale, V.H.; Joyce, L.A.; McNulty, S.; Neilson, R.P.; Ayres, M.P.; Flannigan, M.D.; Hanson, P.J.; Irland, L.C.; Lugo, A.E.; Peterson, C.J.; et al. Climate change and forest disturbances: Climate change can affect forests by altering the frequency, intensity, duration, and timing of fire, drought, introduced species. Bioscience 2001, 51, 723-734. [CrossRef]

6. Seidl, R.; Schelhaas, M.-J.; Rammer, W.; Verkerk, P.J. Increasing forest disturbances in Europe and their impact on carbon storage. Nat. Clim. Chang. 2014, 4, 806-810. [CrossRef] [PubMed]

7. Crowther, T.W.; Glick, H.B.; Covey, K.R.; Bettigole, C.; Maynard, D.S.; Thomas, S.M.; Smith, J.R.; Hintler, G.; Duguid, M.C.; Amatulli, G.; et al. Mapping tree density at a global scale. Nature 2015, 525, 201-205. [CrossRef] 
8. Nelson, H.W.; Williamson, T.B.; Macaulay, C.; Mahony, C. Assessing the potential for forest management practitioner participation in climate change adaptation. For. Ecol. Manag. 2016, 360, 388-399. [CrossRef]

9. Lindner, M.; Garcia-Gonzalo, J.; Kolström, M.; Green, T.; Reguera, R.; Maroschek, M.; Seidl, R.; Lexer, M.J.; Netherer, S.; Schopf, A.; et al. Impacts of Climate Change on European Forests and Options for Adaptation; Report to the European Commission Directorate-General for Agriculture and Rural Development; European Commission: Brussels, Belgium, 2008.

10. Wagner, S.; Nocentini, S.; Huth, F.; Hoogstra, M.A. Forest management approaches for coping with the uncertainty of climate change: Trade-offs in service provisioning and adaptability. Ecol. Soc. 2014, 19, art32. [CrossRef]

11. UN. United Nations Framework Convention on Climate Change. In Proceedings of the 23th UN Climate Change Conference, Bonn, Germany, 6-17 November 2017.

12. Forestry Bureau. Forest Resources Management; Executive Yuan, Council of Agriculture, Forestry Bureau: Taipei, Taiwan, 2020.

13. IPCC. Climate Change; Synthesis Report-Contribution of Working Groups I, II and III to the Fifth Assessment Report of the Intergovernmental Panel on Climate Change Core Writing Team; Pachauri, R.K., Meyer, L.A., Eds.; IPCC: Geneva, Switzerland, 2014.

14. Schoene, D.H.F.; Bernier, P.Y. Adapting forestry and forests to climate change: A challenge to change the paradigm. For. Policy Econ. 2012, 24, 12-19. [CrossRef]

15. Messier, C.; Puettmann, K.; Chazdon, R.; Andersson, K.P.; Angers, V.A.; Brotons, L.; Filotas, E.; Tittler, R.; Parrott, L.; Levin, S.A. From management to stewardship: Viewing forests as complex adaptive Systems in an Uncertain World. Conserv. Lett. 2015, 8, 368-377. [CrossRef]

16. Kolström, M.; Lindner, M.; Vilén, T.; Maroschek, M.; Seidl, R.; Lexer, M.J.; Netherer, S.; Kremer, A.; Delzon, S.; Barbati, A.; et al. Reviewing the science and implementation of climate change adaptation measures in European forestry. Forests 2011, 2, 961-982. [CrossRef]

17. Fernandez-Gimenez, M.E.; Ballard, H.L.; Sturtevant, V.E. Adaptive management and social learning in collaborative and community-based monitoring: A study of five community-based forestry organizations in the western USA. Ecol. Soc. 2008, 13, 4 . [CrossRef]

18. Nocentini, S.; Buttoud, G.; Ciancio, O.; Corona, P. Managing forests in a changing world: The need for a systemic approach. A review. For. Syst. 2017, 26, 1. [CrossRef]

19. Bolte, A.; Ammer, C.; Löf, M.; Madsen, P.; Nabuurs, G.-J.; Schall, P.; Spathelf, P.; Rock, J. Adaptive forest management in central Europe: Climate change impacts, strategies and integrative concept. Scand. J. For. Res. 2009, 24, 473-482. [CrossRef]

20. O'Hara, K.L. What is close-to-nature silviculture in a changing world? Forestry 2016, 89, 1-6. [CrossRef]

21. Gamborg, C.; Larsen, J.B. “Back to nature"-A sustainable future for forestry? For. Ecol. Manag. 2003, 179, 559-571. [CrossRef]

22. Blennow, K.; Persson, J.; Tomé, M.; Hanewinkel, M. Climate change: Believing and seeing implies adapting. PLoS ONE 2012, 7, e50182. [CrossRef]

23. Ciancio, O.; Nocentini, S. Biodiversity conservation and systemic silviculture: Concepts and applications. Plant Biosyst. 2011, 145, 411-418. [CrossRef]

24. Lawrence, A.; Marzano, M. Is the private forest sector adapting to climate change? A study of forest managers in north Wales. Ann. For. Sci. 2013, 71, 291-300. [CrossRef]

25. Yousefpour, R.; Hanewinkel, M. Forestry professionals' perceptions of climate change, impacts and adaptation strategies for forests in south-west Germany. Clim. Chang. 2015, 130, 273-286. [CrossRef]

26. Sousa-Silva, R.; Ponette, Q.; Verheyen, K.; Herzele, A.V.; Muys, B. Adaptation of forest management to climate change as perceived by forest owners and managers in Belgium. For. Ecosyst. 2016, 3, 22. [CrossRef]

27. Joe, B.; Schraml, U. Conservation practiced by private forest owners in Southwest Germany-The role of values, perceptions and local forest knowledge. For. Policy Econ. 2020, 115, 102141. [CrossRef]

28. St-Laurent, G.P.; Hagerman, S.; Findlater, K.M.; Kozak, R. Public trust and knowledge in the context of emerging climate-adaptive forestry policies. J. Environ. Manag. 2019, 242, 474-486. [CrossRef] [PubMed]

29. Findlater, K.M.; Peterson St Laurent, G.; Hagerman, S.; Kozak, R. Surprisingly malleable public preferences for climate adaptation in forests. Environ. Res. Lett. 2020, 15, 034045. [CrossRef]

30. St-Laurent, G.P.; Hagerman, S.; Kozak, R. What risks matter? Public views about assisted migration and other climate-adaptive reforestation strategies. Clim. Chang. 2018, 151, 573-587. [CrossRef]

31. Keenan, R.J. Climate change impacts and adaptation in forest management: A review. Ann. For. Sci. 2015, 72, 145-167. [CrossRef]

32. Altinay, Z. Visual communication of climate change: Local framing and place attachment. Coast. Manag. 2017, 45, 293-309. [CrossRef]

33. Sousa-Silvaa, R.; Verbista, B.; Lombab, Â.; Valentc, P.; Suškevičsd, M.; Picarde, O.; Hoogstra-Kleinf, M.A.; Cosofret, V.-C.; Bouriaudg, L.; Ponetteh, Q.; et al. Adapting forest management to climate change in Europe: Linkingperceptions to adaptive responses. For. Policy Econ. 2018, 90, 22-30. [CrossRef]

34. Blennow, K.; Persson, J. Climate change: Motivation for taking measure to adapt. Glob. Environ. Chang. 2009, 19, 100-104. [CrossRef]

35. Alreck, P.L.; Settle, R.B. The Survey Research Handbook, 3rd ed.; McGraw-Hill: New York, NY, USA, $2004 ;$ p. 496.

36. Singleton, R.A., Jr.; Straits, B.C. Approaches to Social Research, 5th ed.; Oxford University Press: Oxford, UK, 2009 ; p. 672.

37. Babbie, E.R. The Practice of Social Research, 12th ed.; Wadsworth Publishing: Belmont, CA, USA, $2010 ;$ p. 624. 
38. Forestry Bureau. Fourth Forest Resources Survey Report; Executive Yuan, Council of Agriculture, Forestry Bureau: Taipei, Taiwan, 2016.

39. National Statistics Republic of China. Urbanization Area Classification Definition; National Statistics Republic of China: Taipei, Taiwan, 2020.

40. Ministry of the Interior, Department of Household Registration. Demographic Data. 2018. Available online: https://www.ris.gov. tw/app/portal/346 (accessed on 10 February 2021).

41. Wang, P.J.; Lin, J.C.; Chen, Y.H.; Wu, M.S. A study on private forest landowners' perception of forest risks and adaptive forest management strategies to climate change. Quart. J. Chin. For. 2017, 50, 235-250.

42. Wu, Y.C.; Wang, S.Y.S.; Yu, Y.C.; Kung, C.Y.; Wang, A.H.; Los, S.A.; Huang, W.R. Climatology and change of extreme precipitation events in Taiwan based on weather types. Int. J. Clim. 2019, 39, 5351-5366. [CrossRef]

43. Wang, S.Y.; Chen, T.C. Measuring East Asian summer monsoon rainfall contributions by different weather systems over Taiwan. J. Appl. Meteorol. Clim. 2008, 47, 2068-2080. [CrossRef]

44. Ministry of Science and Technology. Taiwan Climate Change Science Report 2017; Executive Yuan, Ministry of Science and Technology: Taipei, Taiwan, 2017.

45. Warren-Wilson, J. An analysis of plant growth and its control in arctic environments. Ann. Bot. 1996, 30, 383-402.

46. Sveinbjörnsson, B.; Nordell, O.; Kauhanen, H. Nutrient relations of mountain birch growth at and below the elevational tree line in Swedish Lapland. Funct. Ecol. 1992, 6, 213-220. [CrossRef]

47. Skre, O. Growth of mountain birch (Betula pubescens Ehrh) in response to changing temperature. In Forest Development in Cold Climates; Alden, J., Mastrantonio, J.L., Ødum, S., Eds.; Plenum Press: New York, NY, USA, 1993; pp. 65-78.

48. Grace, J.; Berninger, F.; Nagy, L. Impacts of climate change on the tree line. Ann. Bot. 2002, 90, 537-544. [CrossRef]

49. André, K.; Bruzell, S.; Gerger Swartling, Å.; Jönsson, A.M.; Lagergren, F.; Vulturius, G.; Blennow, K.; Carlsen, H.; Engström, K.; Hassler, J.; et al. Klimatanpassat Skogsbruk: Drivkrafter, Risker Och Möjligheter; Mistra-SWECIA Syntesrapport; Mistra-Swecia: Stockholm, Sweden, 2015.

50. FAO. Forest Management and Climate Change: Stakeholder Perceptions; Forests and Climate Change Working Paper 11; Food and Agriculture Organization of the United Nations: Rome, Italy, 2013.

51. Coll, L.; Ameztegui, A.; Collet, C.; Löf, M.; Mason, B.; Pach, M.; Verheyen, K.; Abrudan, I.; Barbati, A.; Barreiro, S.; et al. Knowledge gaps about mixed forests: What do European forest managers want to know and what answers can science provide? For. Ecol. Manag. 2018, 407, 106-115. [CrossRef]

52. Fady, B.; Cottrell, J.; Ackzell, L.; Alía, R.; Muys, B.; Prada, A.; González-Martínez, S.C. Forests and global change: What can genetics contribute to the major forest management and policy challenges of the twenty-first century? Reg. Environ. Chang. 2016, 16, 927-939. [CrossRef]

53. Grothmann, T.; Patt, A. Adaptive capacity and human cognition: The process of individual adaptation to climate change. Glob. Reg. Environ. Chang. 2005, 15, 199-213. [CrossRef]

54. Spence, A.; Poortinga, W.; Butler, C.; Pidgeon, N.F. Perceptions of climate change and willingness to save energy related to flood experience. Nat. Clim. Chang. 2011, 1, 46-49. [CrossRef]

55. Reser, J.P.; Bradley, G.L.; Ellul, M.C. Encountering climate change: "Seeing" is more than "believing". Clim. Chang. 2014, 5, 521-537. [CrossRef]

56. Demski, C.; Capstick, S.; Pidgeon, N.; Sposato, R.G.; Spence, A. Experience of extreme weather affects climate change mitigation and adaptation responses. Clim. Chang. 2016, 140, 149-164. [CrossRef]

57. Petr, M.; Boerboom, L.; Ray, D.; van der Veen, A. An uncertainty assessment framework for forest planning adaptation to climate change. For. Policy Econ. 2014, 41, 1-11. [CrossRef]

58. Bruin, J.O.D.; Hoogstra-Klein, M.A.; Mohren, G.M.J.; Arts, B.J.M. Complexity of forest management: Exploring perceptions of Dutch forest managers. Forests 2015, 6, 3237-3255. [CrossRef]

59. Millar, C.I.; Stephenson, N.L.; Stephens, S.L. Climate change and forests of the future: Managing in the face of uncertainty. Ecol. Appl. 2007, 17, 2145-2151. [CrossRef] [PubMed]

60. Lin, W.J. Agricultural technology trends in response to global climate change. Taiwan Econ. Res. Mon. 2011, 34, 38-44.

61. Jhan, S.L.; Li, C.J. Study on the Assessment and Adjustment Strategy of the Vulnerability of Agricultural Land under Climate Change; Executive Yuan, Council of Agriculture 101-114.1.1-Q2; National Taipei University: Taipei, Taiwan, 2012.

62. Kuo, F.Y. Adapting land use policy in the face of climate change: The case of coastal areas in Taiwan. Metrop. Plan. 2010, 37, 47-69.

63. National Science and Technology Center for Disaster Reduction. Report on the Risk Assessment of the Impact of Climate Change Disasters in Taiwan; National Science and Technology Center for Disaster Reduction: New Taipei City, Taiwan, 2016.

64. Lin, H.T.; Kuo, H.C.; Lee, K.P.; Chen, T.C.; Chen, K.T. Experimental analyses on urban heat island effect and its improvement strategies in coastal cities of Taiwan-Analyses for Tainan, Kaohsiung and Hsinchu. Metrop. Plan. 2001, $28,323-341$. 